\title{
DIFFERENCES AMONG CAMIYANI BLACK PINE (PINUS NIGRA ARNOLD. SUBSP. PALLASIANA) CLONES IN SEED ORCHARD BECAUSE OF RHYACIONIA BUOLIANA (DEN. \& SCHIFF) DAMAGES IN TURKEY
}

\author{
YILDIZ, Y.* - ÖZEL, H. B. \\ Department of Forest Engineering, Faculty of Forestry, Bartin University \\ 74100 Bartın, Turkey \\ (phone: +90-378-223-5164; fax: +90-378-223-5066) \\ *Corresponding author \\ e-mail:yafesyildiz@hotmail.com \\ (Received $19^{\text {th }}$ Dec 2018; accepted $14^{\text {th }}$ Feb 2019)
}

\begin{abstract}
This study examined the level of damage caused by pine shoot moth (Rhyacionia buoliana (Den. \& Schiff) between 2014 and 2016 in the seed orchards of Camiyanı Black Pine (Pinus nigra Arnold. subsp. pallasiana (Lamb.) Holmboe). When the variance analysis (ANOVA) was applied, and observations and counts of the seed orchard were evaluated, a statistically significant difference was found between the clones in terms of number of individuals affected by $\mathrm{P}<0.001$. When Duncan Range Test results were examined, 20 groups were formed in total, with a $\mathrm{P}<0.05$ confidence level in terms of the average number of individuals damaged by the pine shoot moth. In this respect, it was determined that the clones which had the highest damage in the seed orchard number 70, clones 21, 25, 26 and 29 were damage the most, while the clones that had the least amount of damage are clones $2,6,8$ and 23. The differences in the average number of clones which the pine shoot moth damage were investigated. When the ANOVA results were examined, it was determined that there was a statistically significant difference in P < 0.001 confidence level between 2014, 2015 and 2016 in terms of the mean number of clones exposed to pine shoot moth damage. There was no significant difference between the blocks in terms of the mean number of clones which the pine shoot moth damaged. When the results of regression analysis were analyzed, strong relationships were found between clone and number of damaged individuals and the number of clones damaged by pine shoots for years.
\end{abstract}

Keywords: Camiyanı Black Pine, seed orchard, clone, Rhyacionia buoliana, Turkey

\section{Introduction}

Forests are special ecosystems that carry out important tasks in protecting the health and ecological balance of the products and services they provide. Therefore, it is important to ensure that the forest resources develop and shape under completely open field conditions, and are protected from harmful biotic and abiotic factors, to ensure the future of humanity. First of all, forests play an important role in the prevention of global warming by mitigating carbon emissions in particular, which is the most relevant environmental problem of our day. Forests transform carbon dioxide through photosynthesis, and store carbon. Thus, it creates an important balance between carbon dioxide and oxygen gases under natural conditions. For example, a well-developed 100year-old beech can absorb up to 40 million $\mathrm{m}^{3}$ of air through photosynthesis, turning $1200 \mathrm{~m}^{3}$ of carbon dioxide in this air to 6 tonnes of carbon as a biochemical transformation. On the other hand, it is reported that a forest can bind 13-30 tons of carbon dioxide for annual compulsory dry biomass production (Görücü and Eker, 2009). However, in today's modern forestry approach, forest resources being used as a multi-faceted collective of services (recreation, erosion prevention, hydrological 
resources, non-wood forest products etc.) are decreasing rapidly both in our country and in the world. As a matter of fact, according to the latest statistical figures, it is reported that the average annual forest loss in the less developed and developing countries has reached approximately $18 \%$ of the world total forest area (FAO, 2016). Our country has valuable ecological, economic and silvicultural forest ecosystems on different elevation levels in terms of tree species type and stand structure characteristics with the effect of different ecological conditions (Saatçioğlu, 1969; Ata, 1995). However, these valuable forest resources, which are estimated to be 22 million hectares in our country, have been significantly damaged by the impact of biotic and abiotic factors such as inadequate technical applications, illegal cuttings, fires, storms, insects and other harmful factors, (GDF, 2016). On the other hand, as a result of the damage caused by these factors in forest resources, $6.7 \%$ of amphibians, birds, mammals and reptiles in the forests, approximately $3.9 \%$ of plant communities, including endemic plants in Turkey are threatened (Kırış and Toprak, 2009). In this context, preserving forest resources is obligatory for the products and services obtained from these sources and for the protection of biodiversity. Successful natural and artificial regeneration promoting methods and afforestation studies are needed to achieve this (Genç, 2004). For this purpose, the use of seedlings produced from genetically modified seed sources is very important in terms of increasing the quality and health of new forests (Tunçtaner, 2007). In this respect, these seed sources are of the highest genetic quality. Seed orchards are important facilities established by high amounts labor, time and money (Ürgenç, 1982). However, these seed sources need to be protected against biotic and abiotic factors to ensure the continuity of genetically improved seed yields from seed orchards. One of the factors that have a negative impact on seed orchards is insect damage. It can reduce seed production by up to $50 \%$ especially in seed orchards with primary pests (Tunçtaner, 2007). The pine shoot moth (Rhyacionia buoliana (Den. \& Schiff) is one of these primary pests that cause significant damage (Çanakçığlu, 1993). Especially Pinus contorta var. latifolia orchards in Sweden, this pest was determined that it was one of the pest caused significant damage (Lindelöw and Björkman, 2001).

In this study, wide area of usage and economically valuable ecotype of the Camiyan Anatolian black pine (Pinus nigra Arnold. subsp. pallasiana (Lamb.) was used. The level of damage on the clones was examined both years, and the most resistant clones were determined.

\section{Materials and methods}

The seed orchard is located in Karabük-Yenice region and is established with cuttings taken from Bakraz region in Yenice of black pine ecotype called Camiyani black pine (Fig. 1). 30 saplings were taken from Bakraz provenance and were planted with an $8 \times 8 \mathrm{~m}$ spacing distance in 1990 in 70 numbered divisions. The seed orchard has a size of 11.3 ha and its elevation is $100 \mathrm{~m}$ with a land slope of $10 \%$. The general exposure of the seed orchard is southern. The soil structure in the seed orchard has clay texture and the $\mathrm{pH}$ varies between 6.06 and 7.80 (Ertekin, 2006). The average annual temperature in the research area is $12.8{ }^{\circ} \mathrm{C}$, with a maximum temperature of $42.8{ }^{\circ} \mathrm{C}$, and a minimum temperature of $-18.6^{\circ} \mathrm{C}$, while the average annual precipitation is $1040.5 \mathrm{~mm}$ with an average relative humidity of $73.6 \%$ (Anonymous, 2016). 


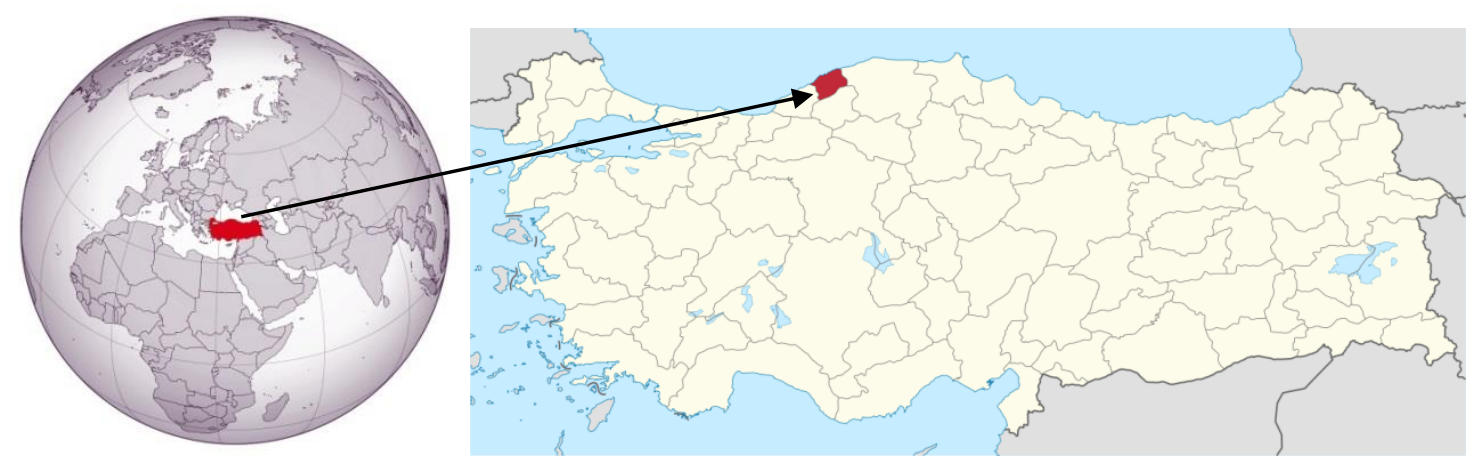

Figure 1. Research area

The seed orchard, which forms the research area, consists of 30 clones and 3 blocks. In this context, in order to determine the damage of pine shoot moth in each block in accordance with the purpose of the study, individuals belonging to all clones were examined. In the research, it was accepted that insect damage occurred in clone in case of damages in single shoot of trees representing clone. In this context, in the 3 blocks of seed orchard, observations and counts were started to be made with the start of vegetation period randomly in the individuals belonging to all clones in the 3 -year period covering 2014-2016, and the individuals whose pine shoot moth damage was detected were separated each year by marking a different color with a spray paint and in this way, the damage occurred in both years is determined and the damage at the level of clones were tried to be determined. In this respect, clones and individuals were identified, while any damage in the height of the tree in a single exile was determined that the clone was considered damaged. Likewise, the same method was applied in similar studies on this subject (Fabre et al., 2004; Turgeon et al., 2004). Thus, the damage caused by the pine shoot moth in the seed orchard has been revealed in the most delicate and detailed manner.

In the study, various statistical analysis methods were used to reveal the pine shoot moth damage in terms of clones, years and blocks in the seed orchard. For this purpose, Kolmogorov-Simirnov (K-S) test was used to determine whether the data obtained from the determinations and counts carried out in the seed orchard during the 3-year period covering 2014-2016. Then, a multi-way ANOVA was applied in order to compare the pine shoot moth losses that occurred due to clones, years and blocks of seed orchard. In the case of a statistically significant difference due to any factor as a result of the variance analysis, Duncan Test was performed, observation years and blocks were required. For this purpose, the mean of the data obtained after observations and determinations for pine shoot moth damage was used (Ercan, 1997). In addition, stepwise regression analyzes were applied to correlate the number of clones with the pine shoot moth. All statistical analyzes were conducted with SPSS 22.0 Statistical Package Program.

\section{Results}

\section{Damages at the clones level}

Figure 2 shows the distribution of the pine shoot moth damages in 2016 as a result of observations and determinations in the seed orchard where the research was carried out. 


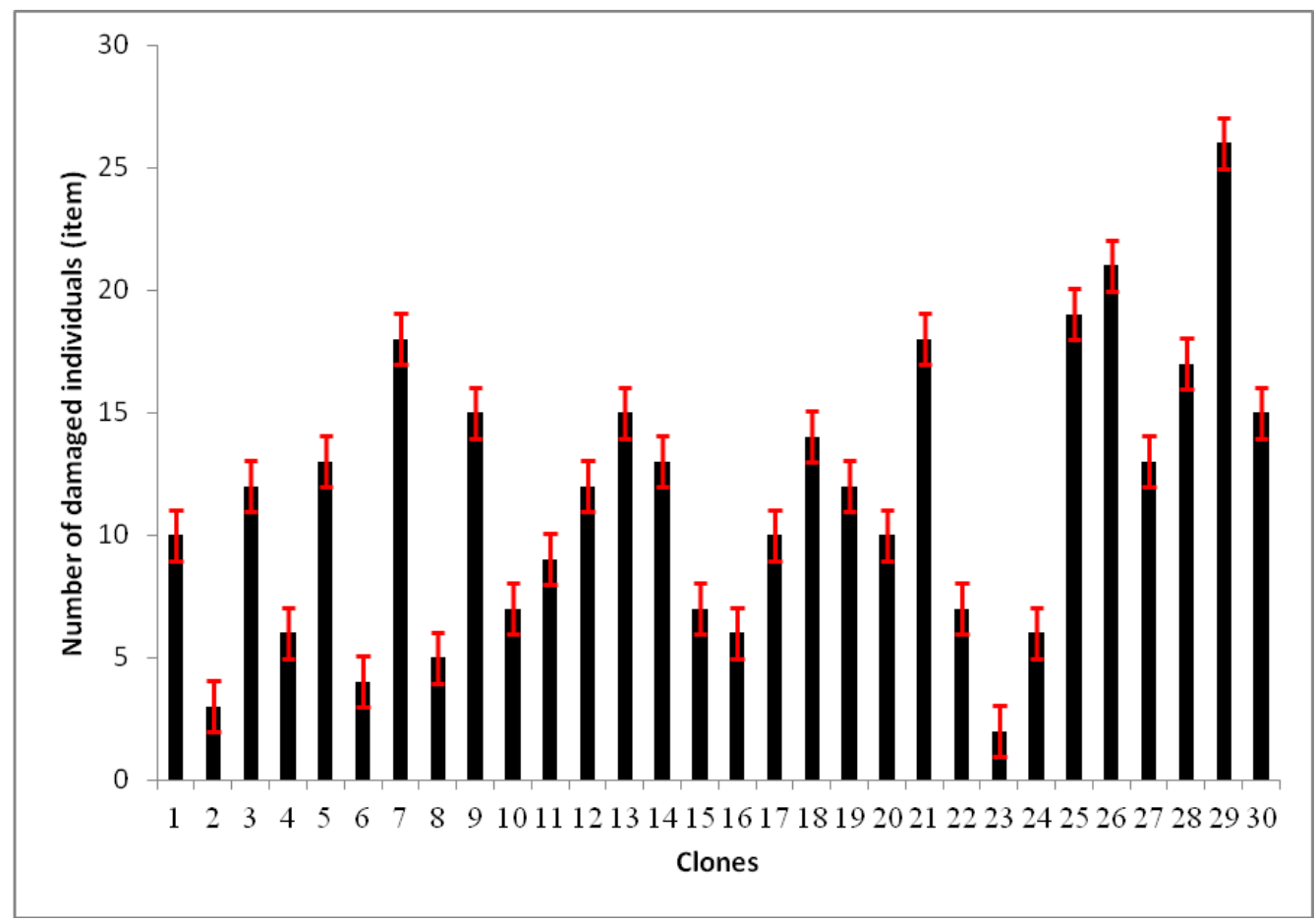

Figure 2. Distribution of number of damaged individuals by clones

As a result of observations and determinations carried out in 2016, it has been determined that the average number of individuals exposed to pine shoot moth damages is between 2.3 and 26.2. In this context, variance analysis was performed to determine whether there was a statistically significant difference between clones in terms of the average number of individuals in which insect damage occurred (Table 1).

Table 1. Results of ANOVA

\begin{tabular}{c|c|c|c|c|c}
\hline Variance sources & Sum of squares & df & Mean square & F & Sig. \\
\hline Between clones & 2857.567 & 29 & 98.537 & 5495.639 & $0.000 * * *$ \\
Within clones & 1.076 & 60 & 0.018 & & \\
Total & 2858.643 & 89 & & & \\
\hline
\end{tabular}

$* * * \mathrm{P}<0.001$ significance level

When ANOVA results in Table 1 were evaluated, it was determined that there was a statistically significant difference between the clones in terms of $P<0.001$. In this context, Duncan Range Test was applied to group clones in terms of the number of individuals in which the pine shoot moth was damaged (Table 2). 
Table 2. Results of Duncan range test

\begin{tabular}{|c|c|c|}
\hline Clones & Number of individuals damaged & Significance level \\
\hline 1 & $10.13^{1}$ & \multirow{30}{*}{$P<0.05$} \\
\hline 2 & $3.13^{\mathrm{t}}$ & \\
\hline 3 & $12.10^{\mathbf{j}}$ & \\
\hline 4 & $6.13^{p}$ & \\
\hline 5 & $13.10^{1}$ & \\
\hline 6 & $4.10^{\mathrm{s}}$ & \\
\hline 7 & $18.10^{\mathrm{e}}$ & \\
\hline 8 & $5.13^{\mathrm{r}}$ & \\
\hline 9 & $15.10^{\mathrm{g}}$ & \\
\hline 10 & $7.12^{\circ}$ & \\
\hline 11 & $9.22^{\mathrm{m}}$ & \\
\hline 12 & $12.20^{\mathbf{j}}$ & \\
\hline 13 & $15.16^{\mathrm{g}}$ & \\
\hline 14 & $13.23^{1}$ & \\
\hline 15 & $7.46^{\mathrm{n}}$ & \\
\hline 16 & $6.10^{\mathrm{p}}$ & \\
\hline 17 & $10.20^{\mathbf{k l}}$ & \\
\hline 18 & $14.23^{\mathbf{h}}$ & \\
\hline 19 & $12.10^{\mathbf{j}}$ & \\
\hline 20 & $10.36^{\mathrm{k}}$ & \\
\hline 21 & $18.46^{\mathrm{d}}$ & \\
\hline 22 & $7.19^{\circ}$ & \\
\hline 23 & $2.1^{\mathrm{u}}$ & \\
\hline 24 & $6.10^{\mathrm{p}}$ & \\
\hline 25 & $19.20^{\mathrm{c}}$ & \\
\hline 26 & $21.13^{\mathbf{b}}$ & \\
\hline 27 & $13.20^{1}$ & \\
\hline 28 & $17.16^{\mathrm{f}}$ & \\
\hline 29 & $26.10^{\mathrm{a}}$ & \\
\hline 30 & $15.20^{\mathrm{g}}$ & \\
\hline
\end{tabular}

When the Duncan Test results in Table 2 were examined, 20 groups were formed in total $P<0.05$ confidence level in terms of the mean number of individuals damaged by pine shoot moth. In terms of the number of injured individuals, clone 29 constitutes the first group alone and clone 23 constitutes the first group. In this respect, it can be said that the clones having the highest damage in the seed orchard 70 are the clones which are the most damaging pine shoot moth.

\section{Damage level according to years}

The change in the mean number of clones that the pine shoot moth has caused damage in the seed orchard in the period of 2014-2016 in which the research was carried out is shown in Figure 3. 


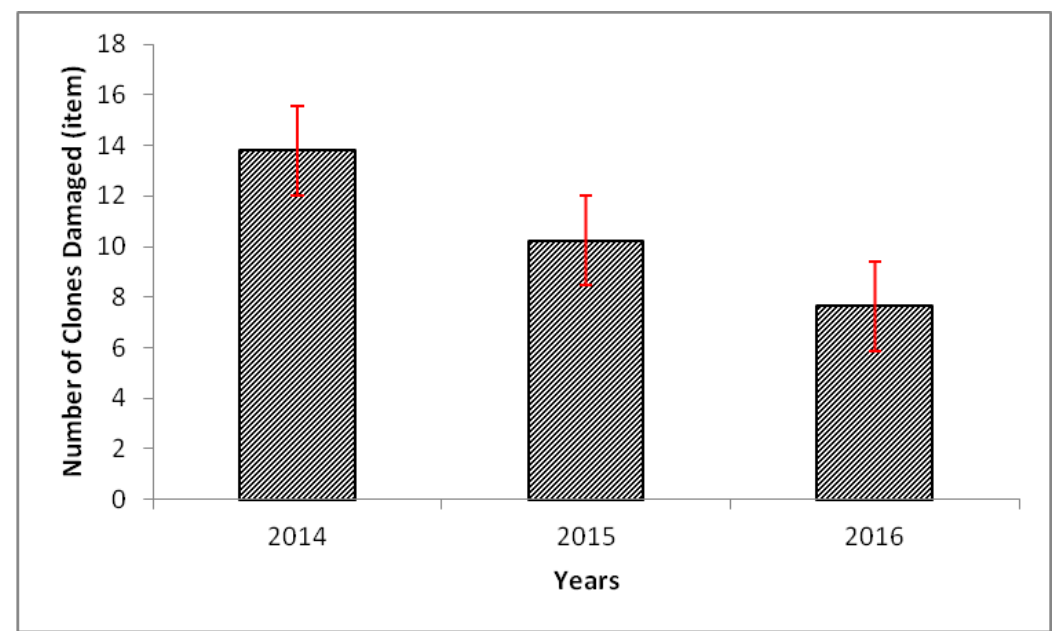

Figure 3. Mean number of clones damaged over the years

According to Figure 3, there is decreasing trend towards 2014 from the year 2016, when the study was conducted in terms of the average number of clones in which pine shoot moth was damaged. According to this, the average number of clones was 13.78 in 2014, 10.23 in 2015 and 7.64 in 2016. Variance analysis was performed to determine if there were any statistical differences in terms of the average number of clones in which pine shoot moth damage occurred (Table 2).

Table 2. Results of ANOVA

\begin{tabular}{c|c|c|c|c|c}
\hline Variance sources & Sum of squares & df & Mean square & F & Sig. \\
\hline Between clones & 2996.314 & 2 & 97.271 & 6987.118 & $0.000^{* * *}$ \\
Within clones & 0.075 & 87 & 0.023 & & \\
Total & 2996.389 & 89 & & & \\
\hline
\end{tabular}

$* * * P<0.001$ significance level

When the ANOVA results in Table 2 were examined, it was determined that there was a statistically significant difference in $\mathrm{P}<0.001$ confidence level between 2014 , 2015 and 2016 in terms of the mean number of clone number exposed to pine shoot moth damage. In this context, Duncan Range Test was applied at $P<0.05$ confidence level and the results are given in Table 3.

Table 3. Results of Duncan range test

\begin{tabular}{c|c|c}
\hline Years & Number of clones damaged & Significance level \\
\hline 2014 & $13.78^{\mathbf{a}}$ & $\boldsymbol{P}<\boldsymbol{0 . 0 5}$ \\
2015 & $10.23^{\mathbf{b}}$ & \\
2016 & $7.64^{\mathbf{c}}$ & \\
\hline
\end{tabular}

As a result of the Duncan Range Test, 3 different groups have emerged in terms of the average number of clones in the $\mathrm{P}<0.05$ confidence level. Accordingly, 2014 was the first group in which the most damages occurred during the 3 -year period during 
which the survey was carried out, while this group was followed by the second group formed by 2015 alone, and 2016 was the third group alone (Table 3).

\section{Damages level according to blocks}

The seed orchard, which forms the research area, consists of three random blocks of experimental design. Therefore, investigations and evaluations have been made in terms of the mean number of clones in which pine shoot moth has caused damage. In this context, the change in the average number of clones that have been damaged in 2016 by blocks is shown in Figure 4.

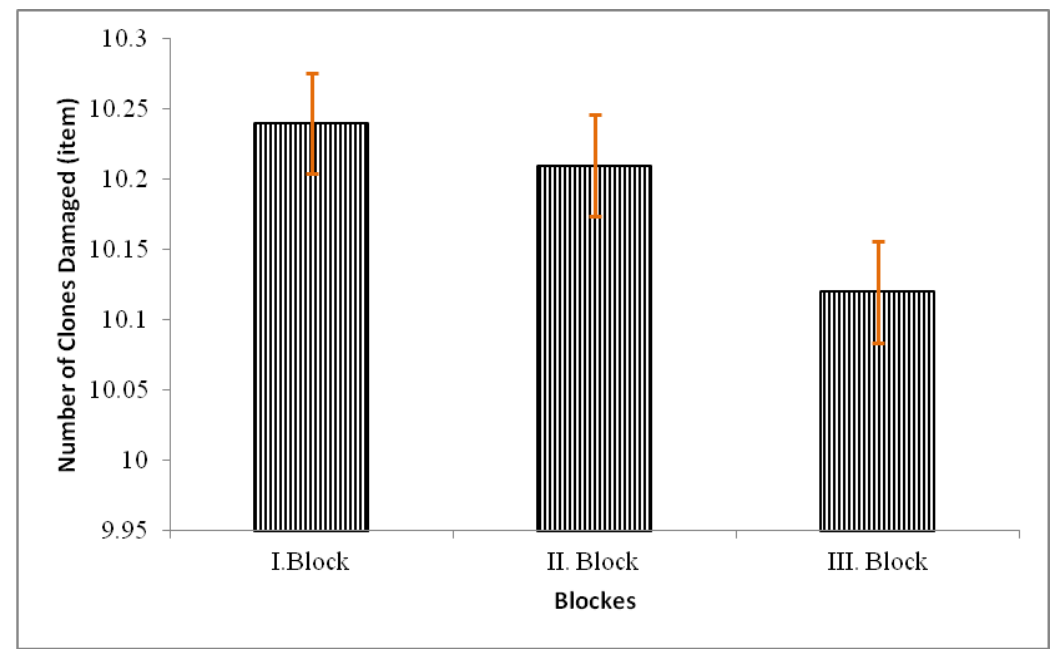

Figure 4. Mean number of clones damaged by blocks

When Figure 4 is examined, it has been determined that there is a tendency towards the decrease in the number of average clone numbers that have been damaged by pine shoot moth as of 2016. According to this study, the average number of damaged clones determined in block I 10.24, block II 10.21 and block III 10.12, respectively. In this context, ANOVA was performed to determine whether there were any statistically significant differences in terms of the mean number of clones exposed to pine shoot moth damage between the blocks (Table 4).

Table 4. Results of ANOVA

\begin{tabular}{c|c|c|c|c|c}
\hline Variance sources & Sum of squares & df & Mean square & F & Sig. \\
\hline Between blocks & 1023.017 & 2 & 0.021 & 0.001 & $0.998^{\text {ns }}$ \\
Within blocks & 0.042 & 87 & 32.857 & & \\
Total & 1023.059 & 89 & & & \\
\hline
\end{tabular}

ns: non significant

According to the analysis of variance in Table 4, it was determined that there were no statistically significant differences between the blocks in terms of the average number of clones in the pine shoot moth. 


\section{The relationships between the variables examined in the research}

In the research, the level of the damage caused by the pine shoot moth 70 in the division seed orchard was determined. For this purpose, detection, counting and observations were made in 3 blocks of seed orchard and 30 clones in the 3 year period of 2014-2016. As a result of detection, counting and observations performed; the number of individuals affected by the clone, the number of clones in which the damage occurred and the number of blocks and the number of clones damaged were also investigated (Table 5). In this respect, stepwise regression analysis method was used.

Table 5. The type, model and relationship degrees of the relationships between variables

\begin{tabular}{c|c|c|c}
\hline Variables & Type of relation & Model & $\mathbf{R}^{\mathbf{2}}$ \\
\hline Number of clone-damaged individuals & Second order polynomial & $\mathrm{y}=0.0171 \mathrm{x}^{2}-0.2474 \mathrm{x}+9.9537$ & 0.95 \\
Years-damaged clones & Linear & $\mathrm{y}=3.07 \mathrm{x}+4.41$ & 0.99 \\
Blocks-damaged clones & Linear & $\mathrm{y}=-0.06 \mathrm{x}+10.31$ & 0.92 \\
\hline
\end{tabular}

When the results of the double regression analysis in Table 5 are examined; a second-order polynomial relationship was found to be positively influenced by the number of individuals affected by the clone. On the other hand, the relationship between the clone and the number of individuals affected by the clone was found to be quite strong $\left(\mathrm{R}^{2}=0.95\right)$. In the study, the relationship between the number of clones damaged by pine shoot moth factor and the years has been investigated. According to this analysis, it was found that there was a strong positive correlation between these two variables $\left(\mathrm{R}^{2}=0.99\right)$ and a positively effective linear relationship. Another double relationship examined in the study is between the blocks and the number of clones damaged by the pine shoots moth. As a result of the study, it was determined that there was a strong $\left(\mathrm{R}^{2}=-0.92\right)$ and a negative effective relationship between these two variables.

\section{Discussion}

In this study, pine shoot moth damage in Yenice-Bakraz provenance of seed orchard which is located in Bartın region were investigated. In research process, there are no determinants of natural factors affecting insect damage. As a result of the determinations and counts conducted between 2014 and 2016, the pine shoot moth has different effects on 30 clones that constitute the seed orchard. For this purpose, according to 2016 data, the average number of individuals exposed to pine shoot moth damage was found to vary between 2.3-26.2 units (Fig. 2). As a result of the variance analysis performed in this context, a significant difference was found between the clones in terms of the number of individuals affected by $\mathrm{P}<0.001$ (Table 1). As a result of this study, 30 clones of $\mathrm{P}<0.05$ confidence level were sequenced and grouped according to the number of individuals affected by pine shoot moth (Table 2). Accordingly, a total of 20 groups were formed as a result of Duncan Range Test. In terms of the number of damaged individuals, clone 29 constitutes the first group alone and clone 23 constitutes the first group. In this respect, it can be said that the clones which have the highest damage in the seed orchard 70 number division which is the research subject of the pine shoot moth are clones with 21, 25, 26 and 29 clones and the 
clones with the least damage are clones with 2, 6, 8 and 23 (Table 2). As a matter of fact, there is a Pinus contorta var. latifolia plantations in Sweden have caused significant damages, and in this context, the clonal production of the species and the need to determine the origin of local clones resistant to these and similar pests are emphasized (Lindelöw and Björkman, 2001). On the other hand, a study conducted at Bosnian Pine (Pinus helderichii H. Christ. (1863) syn. Pinus leucodermis Ant. (1864)) found that pine shoot moth caused different rate of damage in the natural distribution area of the Bosnian pine and the seed sources established at the origin level (Vendramin et al., 2003). A study conducted in New Zealand on Pinus radiata found that some insect species, such as pine shoot moth, as well as snow, frost and drought damages caused significant damages in plantations and genetically modified seed sources; therefore, it has been reported that clones and origins are obtained from these damaging factors by intra-site crossover studies (Dungey et al., 2003). In this context, in the light of the results obtained from this research carried out in the Camiyanı black pine, it can be said that the clones, which the pine shoot moth has created the least damage during the 3-year period, constitute an important potential in terms of resistance improvement studies against this pest. There are significant benefits in monitoring the temporal course of damage to examine the effects of bacterial, fungus and insect on forest resources. In this study, the damage caused by the pine shoot moth on clones in the seed orchard in 2014, 2015 and 2016 was investigated. According to the results of 3-year observations and determinations, the average number of clones in 2014 was 13.78, in 2015 it was 10.23 and 7.64 was in 2016 (Fig. 3). As a result of the variance analysis, it was found that there was a statistically significant difference in $\mathrm{P}<0.001$ confidence level between the years in terms of the average number of clones that the pine bendtwist caused by membrane (Table 2). In this context, Duncan Range Test was applied at $\mathrm{P}<0.05$ confidence level. As a result of the Duncan Range Test performed, 3 different groups emerged in terms of the average clone number variable damaged by pine shoot moth at $\mathrm{P}<0.05$ confidence level. Accordingly, 2014 was the first group in which the most damages occurred during the 3-year period during which the survey was carried out, while this group was followed by the second group formed by 2015 alone, and 2016 was the third group alone (Table 3). Accordingly, it is possible to say that there is a significant decrease in the level of the damage caused by the pine shoot moth in the seed orchard. As a matter of fact, in a study conducted in Canada, pheromone traps placed in natural forest area, special seed sources and city centers were determined to show significant increases in monthly and yearly periods of pine shoot moth population in periods when the average temperature was above $-2.2^{\circ} \mathrm{C}$ (Heeley et al., 2003). On the other hand, in a study conducted in China, it has been determined that 39 insect species detected in native coniferous species are continuous and if the necessary measures are not taken, the severity of this situation increases. As a matter of fact, in the same study, it was found that there were many insect in the fir trees of spruce, douglas fir and hybrid species in China (26 species), and that the same insects caused significant damages in the seeds of 72 broad leaf species in the world in a very short time (Roques et al., 2003). In another study, it has been tried to determine the damages caused by Rhyacionia frustrana (Comstock) which is a different species of pine shoot moth in the seed orchard of the Turkish Red Pine (Pinus brutia Ten.) it has been determined that the pine shoot moth, especially in green cones, has caused damage that has a high rate of severity in different periods of different years (Can and Özçankaya, 2006). 
In the seed orchard with the necessary examination and determinations in the study, 3 random blocks were formed depending on the experimental design in the organization and the average clone numbers were determined in the blocks in which the pine shoot moth was damaged (Fig. 4). As of 2016, pine shoot moth has been damaged in terms of the average number of clones in Block I, III. A downward trend towards the block was determined. Accordingly, the average number of damaged clones determined in Block I as a result of the findings and counts performed in 2016 was 10.24, II. The average number of damaged clones detected in the block was 10.21 and III. The average number of damaged clones detected in the block was 10.12. In this context, variance analysis was performed to determine whether there were any statistically significant differences in terms of the mean number of clones exposed to pine shoot moth damage between the blocks (Table 4). As a result of the analysis of variance, no statistically significant difference was found between the blocks in terms of the average number of clones in which the pine shoot moth was harmful (Table 4). As a matter of fact, no studies have been carried out in Sweden about the difference in damage caused by pine shoot moth between blocks in seed orchard (Lindelöw and Björkman, 2001). In another research carried out in the Pinus brutia seed orchard in Turkey, there was no significant difference between the blocks in terms of the average number of clones exposed to the damage caused by the pine shoots (Can and Özçankaya, 2006). In this study, which was carried out over a 3-year period covering the years 2014-2016, the relationship between the number of individuals affected by the clone, the number of clones damaged by years, and the number of blocks and the number of clones damaged were also investigated with the help of binary regression analysis (Table 5). When the results of the binary regression analysis are examined; a second-order polynomial relationship was found to be positively influenced by the number of individuals affected by the clone. On the other hand, it was found that the relationship between the clone and the number of individuals damaged was quite strong $\left(\mathrm{R}^{2}=0.95\right)$. In the study, the relationship between the number of clones damaged by pine shoot moth factor and the years has been investigated. According to this analysis, it was found that there was a strong positive relationship $\left(\mathrm{R}^{2}=0.99\right)$ between these two variables. Another double relationship examined in the study is between the blocks and the number of clones damaged by the pine shoots moth. As a result of the study, it was found that there was a strong $\left(\mathrm{R}^{2}=-0.92\right)$ and negative relationship between these two variables (Table 5). These strong relationships have also enabled the creation of some models and use in practice in determining the extent of the damage to be caused by the pine shoot moth in the seed production (Table 5). The strong relationships between the variables investigated in this study were obtained in a similar study of Pinus radiata seed sources (Dungey et al., 2003).

\section{Conclusions}

In this research carried out in the seed orchard number 70 of Camiyani black pine, an important ecotype of black pine, which has a wide natural distribution area and geographical variation in Turkey, significant time, effort and money were spent in established, were damaged by the Rhyacionia buoliana level of the damage was investigated between 2014-2016. In this study, although no determinations and determinations have been made about the effects of clones on seed efficiency, which caused a particularly high level of damage, a research was carried out which is 
important in terms of the damage caused in the seed orchard and the determination of clones that can be resistant to this damage. In accordance with the information obtained from this research, the level of damage caused by pine shoot moth should be closely monitored in the seed orchard which constitutes the research object. More detailed studies should be determined precisely and the chemical and biological control should be started in a planned way without any loss of time in order to prevent these pests from causing damages that cause greater losses in the seed orchard. On the other hand, in accordance with the findings obtained from the research, it was determined that the clones that were affected from the shoot moth caused by the environmental conditions of the seed orchard were the least affected clones 2, 6, 8 and 23 respectively. Accordingly, planned vegetative reproduction of these clones, which are determined to be resistant to this pest, in the form of residual breeding techniques and use in afforestation studies of individuals obtained by clonal production with cuttings taken from clones, biotic and abiotic causes caused by the change of environmental conditions of afforestation and artificial regeneration studies. Resistance to pests will significantly improve your success.

Acknowledgements. We would like to thank the General Directorate of Forestry, Forest Trees and Seed Breeding Research Institute for their support and contribution at every stage of this research.

\section{REFERENCES}

[1] Anonymous (2016): Meteorological Data of Bartın Province. - General Directorate of Meteorology Press, Ankara.

[2] Ata, C. (1995): Basic Principles of Silviculture. - ZKÜ, Bartın Forestry Faculty Press, No: 1, Bartın.

[3] Can, P., Özçankaya, M. (2006): Determination of cone pests and control methods in seed orchard in Aegean Region. - Directorate of Aegean Forest Research Institute Press, No: 35/254, İzmir.

[4] Çanakçıŏlu, H. (1993): Forest Entomology (Special Section). - University of İstanbul, Faculty of Forestry Press, No: 412/3623, İstanbul.

[5] Dungey, H. S., Carson, M. J., Low, C. B., King, N. G. (2003): Potential and niches for inter-specific hybrids with Pinus radiata in New Zealand. - New Zealand Journal of Forestry Science 33(3): 295-318.

[6] Ercan, M. (1997): Statistic in Scientific Research. - Directorate Poplar and Fast Growing Forest Tree Species Research Institute, İzmit.

[7] Ertekin, M. (2006): Clonal variations in flowering, cone production and seed characteristics of black pine (Pinus nigra Arnold. subsp. pallasiana (Lamb.) Holmboe) seed orchard originated from Yenice-Bakraz. - PhD Thesis, Zonguldak Karaelmas University, Graduate School of Natural and Applied Sciences, Department of Forest Engineering, Bartın.

[8] Fabre, J. P., Auger-Rozenberg, M. A., Chalon, A., Boivin, S., Roques, A. (2004): Competition between exotic and native insects for seed resources in trees of a Mediterranean forest ecosystem. - Biological Invasions 6(1): 11-22.

[9] FAO (2016): FAO. State of The World's Forests 2016. - Food and Agriculture Organization of the United Nations, Rome.

[10] GDF (2016): Forests of Turkey. - General Directorate of Forestry Press, Ankara.

[11] Genç, M. (2004): Techniques of Silviculture. - S.D.Ü Faculty of Forestry Press, No: 46, Isparta. 
[12] Görücü, Ö., Eker, Ö. (2009): The research on carbon emission and economics in the watershed of Kahramanmaraş Ayvalı Dam. - Proceedings of the II. Congress on SocioEconomic Issues in Forestry, S.D.Ü., Istparta, pp. 19-21.

[13] Heeley, T., Alfaro, R. I., Humble, L., Strong, W. (2003): Distribution and life cycle of Rhyacionia buoliana (Lepidoptera: Tortricidae) in the interior of British Columbia. Journal of the Entomological Society of British Columbia 100: 19-25.

[14] Kırış, R., Toprak, S. (2009): Role of Forests in Climate Change. - Proceedings of the II. Congress on Socio-Economic Issues in Forestry, S.D.Ü. Isparta, pp. 379-384.

[15] Lindelöw, Å., Björkman, C. (2001): Insects on lodgepole pine in Sweden-current knowledge and potential risks. - Forest Ecology and Management 141(1): 107-116.

[16] Roques, A., Sun, J. H., Auger-Rozenberg, M. A., Hua, O. (2003): Potential invasion of China by exotic insect pests associated with tree seeds. - Biodiversity \& Conservation 12(11): 2195-2210.

[17] Saatçioğlu, F. (1969): Biological Basics and Principles of Silviculture. - University of İstanbul Press, No: 138/1429, İstanbul.

[18] Tunçtaner, K. (2007): Forest Genetic and Tree Improvement. - Turkey Foresters Association Press, Ankara.

[19] Turgeon, J. J., Jones, C., Bellocq, M. I. (2004): Seed cone traits and insect damage in Tsuga canadensis (Pinaceae). - Canadian Journal of Forest Research 34(1): 261-265.

[20] Ürgenç, S. (1982): Forest Tree Improvement, University of İstanbul. - Faculty of Forestry Press, No: 2836/293, İstanbul.

[21] Vendramin, G. G., Fineschi, S., Fady, B. (2003): Technical Guidelines for Genetic Conservation and Use of Bosnian Pine (Pinus helderichii H. Christ. (1863) syn. Pinus leucodermis Ant. (1864)). - EUFORGEN Technical Report, Bonn. 